\title{
The Effect of Saline Solution Used as an Activating Factor of the Semen in Brown Trout, Salmo Trutta Fario (Linnaeus 1758)
}

\author{
Paul UIUIU ${ }^{1}$, Daniel I. COCAN ${ }^{1}$, Călin LAȚIU ${ }^{1}$, Tudor PĂPUC, Florentina POPESCU ${ }^{1}$, Radu \\ CONSTANTINESCU ${ }^{1}$, Cristian O. COROIAN ${ }^{1}$, Andrada IHUȚ ${ }^{1}$,Vioara MIREŞAN ${ }^{1 *}$ \\ ${ }^{1}$ Faculty of Animal Science and Biotechnologies, University of Agricultural Sciences and Veterinary \\ Medicine Cluj-Napoca, 3-5 Mănăștur Street, 400372, Romania \\ *Corresponding author, e-mail: vmiresan@yahoo.com; vioara.miresan@usamvcluj.ro
}

Bulletin UASVM Animal Science and Biotechnologies 74(2)/ 2017

Print ISSN 1843-5262; Electronic ISSN 1843-536X

DOI:10.15835/buasvmcn-asb: 0028

\begin{abstract}
In this research we analysed the phenotypic characterization of Salmo trutta fario species and we studied the effect of the saline solution used as an activator for seminal material. The spermatozoa mobility ratio in our study ranged from $60 \%$ to $95 \%$, with an average of $74 \%$ when using water and $84.5 \%$ when a saline solution $(\mathrm{NaCl})$ of $7 \%$ was used. The average mobility time ranges between 58.7 seconds (water) and 99 seconds (saline solution). Biochemical analyses of seminal plasma were performed and parameters such as ions concentration $\left(\mathrm{Na}^{+}, \mathrm{K}^{+}, \mathrm{Ca}^{2+}\right.$ $, \mathrm{Mg}^{2+}, \mathrm{Cl}^{-}$), protein profile (BUN, TP), lipid profile (TG, Chol) and enzyme profile (ALP) were followed. As a result of our research on semen in brown trout, we noticed that saline solution (7\%) compared to water when used as an activator of seminal material, is more effective in activating spermatozoa.
\end{abstract}

Keywords: mobility duration, seminal plasma, spermatocrit, viability

\section{INTRODUCTION}

The brown trout, Salmo trutta fario (Linnaeus, 1758 ) is a species of great importance in fish farming, so an assessment of sperm quality can contribute to an increase in the effectiveness of artificial fertilization (Dziewulska and Domagala, 2002).

In Salmonids, the disposal of semen is done externally, a period of time being necessary between sperm release and fertilization of eggs during which sperm have to retain fertilization capacity (Lahnsteiner et al., 1998, Cosson, 2004). Thus, to gather high rates of fertilization, it is necessary to achieve several factors, such as mobility (Alavi and Cosson, 2005, 2006; Curon et al., 1999; Rurangwa et al., 2004) viability (Hajirezaee et al., 2010; Ingermann et al., 2002; Lahnsteiner, 2007; Nynca and Ciereszko, 2009), spermatocrit and sperm density (Ciereszko et al.,
2010; Lahnsteiner et al., 2010), factors that are interdependent.

Salmonids spermatozoa, as well as in other species, are immobile in the seminal tract and are activated only in the dilution with a suitable fertilization medium (Billiard, 1987a; Ingermann et al., 2008). Other studies were conducted to determinate a proper solution for the activation of semen (Nynca et al, 2012; Woolsey et al, 2006; Zuccarelli et al., 2007), thus, saline media of different concentrations were used (Billard, 1978; Billard, 1987b; Brown et al., 1994).

\section{MATERIALS AND METHODS}

The biological material used in this study was sampled from Fiad trout farm, Bistrița-Năsăud County. The number of specimens from which samples were taken was 10 males, 6 years of age. Clinically healthy specimens were used in order 
Tab. 1. The chemical composition of administered feed (Source:www. aller-aqua.com)

\begin{tabular}{ccc}
\hline \multirow{2}{*}{ Specification } & \multicolumn{2}{c}{ Granulation } \\
\cline { 2 - 3 } & $6 \mathrm{~mm}$ & $8 \mathrm{~mm}$ \\
\hline Crude protein (\%) & 53 & 53 \\
\hline Crude fat (\%) & 14 & 14 \\
\hline NFE (\%) & 15,5 & 15,5 \\
\hline Ash (\%) & 8,2 & 8,2 \\
\hline Fiber (\%) & 1,3 & 1,3 \\
\hline Digestible energy (MJ) & 19,2 & 19,2 \\
\hline Vitamin A (IU) & 10.000 & 10.000 \\
\hline Vitamin $\mathrm{D}_{3}(\mathrm{IU})$ & 1.000 & 1.000 \\
\hline Vitamin E (IU) & 200 & 200
\end{tabular}

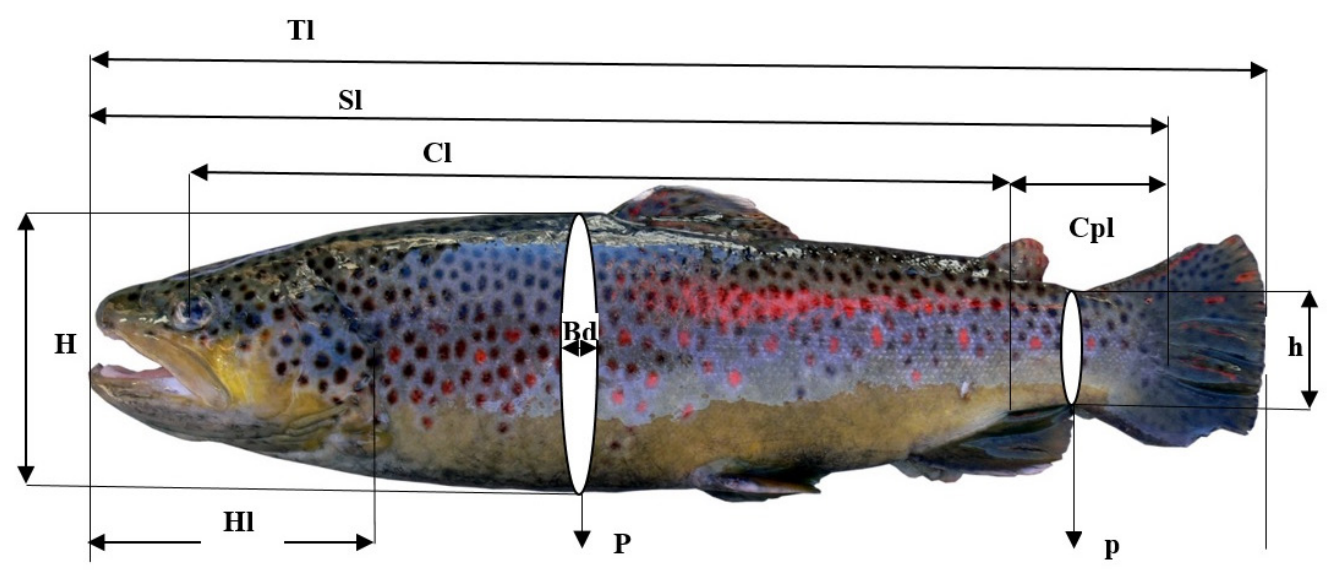

Fig. 1. Somatic measurements made in brown trout males

Note: $\mathbf{T l}$ - total length; $\mathbf{S l}$ - standard length; $\mathbf{C l}$ - commercial length; $\mathbf{H}$ - maximum height; $\mathbf{h}$ - minium height; $\mathbf{H l}$ - head length; Cpl - caudal peduncle length; $\mathbf{P}$ - large perimeter; $\mathbf{p}$ - small perimeter; Bd - body depth.

not to negatively affect the obtained results. The study took place during December 2015-January 2016. The feed administrated to the breeders group (Tab. 1) was Aller Aqua, Aller Rep Ex 6 - 8 $\mathrm{mm}$.

To obtain the semen samples, the trout specimens were anesthetized prior to harvesting with clove oil, $0.047 \mathrm{ml} / \mathrm{L}$ concentration in water (Eugenia caryophyllata), a solution used as a local antiseptic and anesthetic. After anesthetization, with a gentle pushing motion along the abdomen, the semen was transferred into Eppendorf tubes. Immediately after harvesting of the semen, the Eppendorf tubes were introduced in an isothermal bag at a temperature of $4{ }^{\circ} \mathrm{C}$.

For the phenotypic characterization of the species, 11 somatic measurements were performed (Fig.1), which were made on the digital photographs taken, with ToupView-AmScope software.

To determine sperm mobility and viability (Fig. 2), water and saline solution ( $\mathrm{NaCl}-7 \%$ ) were used. $1 \mu \mathrm{l}$ of semen was diluted in $20 \mu \mathrm{l}$ of water and $1 \mu \mathrm{l}$ of semen was diluted in $20 \mu \mathrm{l}$ of saline solution ( $\mathrm{NaCl}-7 \%$ ). The microscope used was equipped with a Nikon D300 camera and 60x objective was used.

The sperm density was performed by microscopic examination; sperm count was made in one millilitre of semen, using the Bürker-Türk chamber. Mett tubes were used to determine the spermatocrit, which was centrifuged at $4500 \mathrm{rpm}$ for 5 minutes to separate seminal plasma from spermatocrit. 


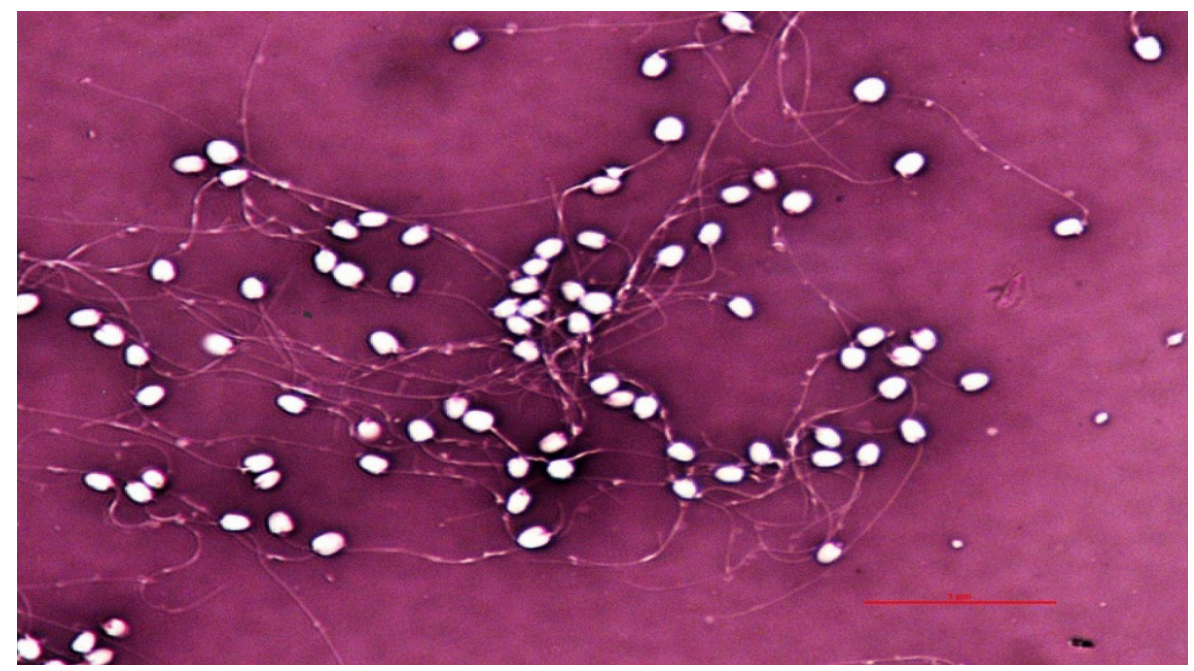

Fig. 2. Spermatozoa captured from microscope using Nikon D300 camera

Tab. 2. Wavelength reading $(\lambda)$ for biochemical analyses on seminal plasma in brown trout

\begin{tabular}{cccc}
\hline Specifications & Abbr. & MU & $\lambda$ \\
\hline Mineral profile & & & \\
\hline Sodium & $\mathrm{Na}^{+}$ & $\mathrm{mmol} / \mathrm{L}$ & $405 \mathrm{~nm}$ \\
\hline Potassium & $\mathrm{K}^{+}$ & $\mathrm{mmol} / \mathrm{L}$ & $380 \mathrm{~nm}$ \\
\hline Calcium & $\mathrm{Ca}^{2+}$ & $\mathrm{mg} / \mathrm{dl}$ & $575 \mathrm{~nm}$ \\
\hline Magnesium & $\mathrm{Mg}^{2+}$ & $\mathrm{mg} / \mathrm{dl}$ & $560 \mathrm{~nm}$ \\
\hline Chlorine & $\mathrm{Cl}^{-}$ & $\mathrm{mmol} / \mathrm{L}$ & $520 \mathrm{~nm}$ \\
\hline Protein profile & & & \\
\hline Urea & $\mathrm{BUN}$ & $\mathrm{mg} / \mathrm{dl}$ & $340 \mathrm{~nm}$ \\
\hline Total Protein & $\mathrm{TP}$ & $\mathrm{g} / \mathrm{dl}$ & $546 \mathrm{~nm}$ \\
\hline Lipid profile & & & \\
\hline Tryglicerides & $\mathrm{TG}$ & $\mathrm{mg} / \mathrm{dl}$ & $550 \mathrm{~nm}$ \\
\hline Cholesterol & $\mathrm{Chol}$ & $\mathrm{mg} / \mathrm{dl}$ & $500 \mathrm{~nm}$ \\
\hline Enzyme profile & & & \\
\hline Alkaline phosphatase & $\mathrm{ALP}$ & $\mathrm{U} / \mathrm{L}$ & $405 \mathrm{~nm}$ \\
\hline
\end{tabular}

Biochemical analyses performed on seminal plasma were represented by the mineral profile: sodium $\left(\mathrm{Na}^{+}\right)$, potassium $\left(\mathrm{K}^{+}\right)$, calcium $\left(\mathrm{Ca}^{2+}\right)$, magnesium $\left(\mathrm{Mg}^{2+}\right)$, chlorine $(\mathrm{Cl})$; protein profile: urea (BUN), total protein (TP); lipid profile: triglycerides (TG), cholesterol (Chol) and enzymatic profile: alkaline phosphatase (ALP). All analyses were performed by MasterTouch spectrophotometer by reading the wavelengths (Tab.2.) at the pre-set values.

The obtained data was interpreted and processed statistically with the GraphPad Prism v6 software. Drafting, images, graphics and spreadsheets were edited in Microsoft Word v. 2013 and Adobe Photoshop CC 2017. All the methods used are up-to-date and the existing data has been obtained in the laboratories of USAMV Cluj-Napoca, Faculty of Animal Science and Biotechnology, discipline Physiology of Aquatic Organisms.

\section{RESULTS AND DISCUSSIONS}

The mean body mass (Table 3 ) was $0.96 \pm 0.07$ $\mathrm{kg}$ with a minimum of $0.67 \mathrm{~kg}$ and a maximum of $1.39 \mathrm{~kg}$. The coefficient of variability of body mass had an average of $22.23 \%$. This shows the 
Tab. 3. The mean values of somatic measurements in brown trout (Salmo trutta fario) males at age of six years $(n=10)$

\begin{tabular}{cccccccc}
\hline Specification & Abbreviation & MU & X \pm SEM & Minimum & Maximum & V\% & SD \\
\hline Body mass & $\mathrm{Bw}$ & $\mathrm{kg}$ & $0.96 \pm 0.07$ & 0.67 & 1.39 & 22.23 & 0.21 \\
\hline Total length & $\mathrm{Tl}$ & $\mathrm{cm}$ & $42.37 \pm 0.92$ & 38.90 & 48.82 & 6.84 & 2.90 \\
\hline Standard length & $\mathrm{Sl}$ & $\mathrm{cm}$ & $38.84 \pm 0.85$ & 35.53 & 44.64 & 6.91 & 2.68 \\
\hline Commercial length & $\mathrm{Cl}$ & $\mathrm{cm}$ & $29.13 \pm 0.71$ & 26.26 & 33.71 & 7.70 & 2.24 \\
\hline Maximum height & $\mathrm{H}$ & $\mathrm{cm}$ & $9.99 \pm 0.29$ & 8.48 & 11.57 & 9.34 & 0.93 \\
\hline Minimum height & $\mathrm{H}$ & $\mathrm{cm}$ & $4.03 \pm 0.08$ & 3.54 & 4.48 & 6.18 & 0.25 \\
\hline Head length & $\mathrm{Hl}$ & $\mathrm{cm}$ & $10.08 \pm 0.20$ & 9.21 & 11.63 & 6.34 & 0.64 \\
\hline Caudal peduncle length & $\mathrm{Cpl}$ & $\mathrm{cm}$ & $5.95 \pm 0.12$ & 5.41 & 6.66 & 6.45 & 0.38 \\
\hline Large perimeter & $\mathrm{P}$ & $\mathrm{cm}$ & $30.56 \pm 1.09$ & 25.53 & 36.81 & 11.34 & 3.47 \\
\hline Small perimeter & $\mathrm{P}$ & $\mathrm{cm}$ & $12.47 \pm 0.31$ & 10.70 & 13.83 & 7.78 & 0.97 \\
\hline Body depth & $\mathrm{Bd}$ & $\mathrm{cm}$ & $6.59 \pm 0.38$ & 5.23 & 8.88 & 18.31 & 1.21 \\
\hline
\end{tabular}

Tab. 4. The mean values of maintenance indices in brown trout $(n=10)$

\begin{tabular}{ccccccc}
\hline Indices & Abbreviation & $\mathrm{X} \pm$ SEM & Minimum & Maximum & V\% & SD \\
\hline Fulton & $\mathrm{K}$ & $6.72 \pm 0.35$ & 5.17 & 8.54 & 16.51 & 1.11 \\
\hline Profile & $\mathrm{Ip}$ & $3.90 \pm 0.08$ & 3.61 & 4.32 & 6.23 & 0.24 \\
\hline Thickness & $\mathrm{Ig}$ & $16.92 \pm 0.73$ & 13.83 & 19.88 & 13.75 & 2.33 \\
\hline Kiselev & $\mathrm{IK}$ & $1.28 \pm 0.03$ & 1.17 & 1.45 & 7.70 & 0.10 \\
\hline Carnality 1 & Ic1 & $25.99 \pm 0.38$ & 23.92 & 27.69 & 4.66 & 1.21 \\
\hline Carnality 2 & Ic2 & $15.33 \pm 0.22$ & 13.74 & 16.20 & 4.50 & 0.69 \\
\hline
\end{tabular}

existence of a good homogeneity of the breeding group.

Analysing the total length, it has an mean value of $42.37 \pm 0.92 \mathrm{~cm}$, its variability being $6.84 \%$, with a minimum length of $38.9 \mathrm{~cm}$ and the maximum of $48.82 \mathrm{~cm}$. Regarding the variability coefficient of the studied characters, average variables are recorded for body weight and body depth, at the opposite pole, with low variables, the other 9 somatic studied characters. Overall, these low variability values indicate that this group of breeders is homogeneous, and that frequent sorting of breeding groups is performed within the Fiad trout farm.

Body indices (Tab. 4.) help us in selection of specimens for the breeding nucleus. Thus, the Fulton condition factor (K) shows the fish maintenance status, the mean value of this body index is $6.72 \pm 0.35$, which confirms that the fish maintenance status is good.

The profile index (Ip) highlights the body shape of the fish and allows individuals from a population to fit into a particular type of profile.
Thus, in our case we have a low index value (3.90 \pm 0.08 ), showing that fish have a pronounced spine convexity, which is correlated with a rich muscle mass in the trunk region.

The thickness index (Ig) expresses the depth of the body in its most developed region reported to the standard length of the fish. Its mean value is high (16.92 \pm 0.73$)$, so the fish will show better development of the lateral muscles.

The quality index, Kiselev (IK), gives us information on quality of fish, based on Kiselev relationship. The mean value of this index is small $(1.28 \pm 0.03)$, this value denoting a richer muscle mass due to the fact that the specimens have a longer circumference than the length.

The carnosity index (Ic1 - Ic2) is the ratio of the caudal head or peduncle in the standard length of the body. This index record a mean value of $25.99 \pm 0.38$ (Ic1) and $15.33 \pm 0.22$ (Ic2), thus, the fish have a high percentage of meat. The fact that carnosity index values fluctuate around $20 \%$, indicates that the studied specimens have proper 
Tab. 5. The mean values of biochemical analysis of seminal plasma in brown trout (Salmo trutta fario) males at age of six years $(\mathrm{n}=10)$

\begin{tabular}{|c|c|c|c|c|c|c|c|}
\hline Specifications & Abbr. & MU & $\mathrm{X} \pm \mathrm{SEM}$ & Min. & Max. & $\mathrm{V} \%$ & SD \\
\hline \multicolumn{8}{|l|}{ Mineral profile } \\
\hline Sodium & $\mathrm{Na}^{+}$ & $\mathrm{mmol} / \mathrm{L}$ & $107 \pm 1.04$ & 94.00 & 124.00 & 9.72 & 10.403 \\
\hline Potassium & $\mathrm{K}^{+}$ & $\mathrm{mmol} / \mathrm{L}$ & $12.8 \pm 0.17$ & 10.50 & 15.00 & 13.01 & 1.665 \\
\hline Calcium & $\mathrm{Ca}^{2+}$ & $\mathrm{mg} / \mathrm{dl}$ & $4.06 \pm 0.16$ & 2.70 & 6.20 & 28.33 & 1.150 \\
\hline Magnesium & $\mathrm{Mg}^{2+}$ & $\mathrm{mg} / \mathrm{dl}$ & $2 \pm 0.054$ & 1.30 & 3.10 & 27.18 & 0.544 \\
\hline Chlorine & $\mathrm{Cl}^{-}$ & $\mathrm{mmol} / \mathrm{L}$ & $104.8 \pm 0.91$ & 94.60 & 121.50 & 8.70 & 9.116 \\
\hline \multicolumn{8}{|l|}{ Protein profile } \\
\hline Urea & BUN & $\mathrm{mg} / \mathrm{dl}$ & $12.3 \pm 0.15$ & 10.40 & 14.60 & 11.95 & 1.470 \\
\hline Total Protein & $\mathrm{TP}$ & $\mathrm{g} / \mathrm{dl}$ & $0.25 \pm 0.01$ & 0.17 & 0.32 & 20.91 & 0.052 \\
\hline \multicolumn{8}{|l|}{ Lipid profile } \\
\hline Tryglicerides & TG & $\mathrm{mg} / \mathrm{dl}$ & $4.13 \pm 0.07$ & 3.20 & 5.20 & 16.66 & 0.688 \\
\hline Cholesterol & Chol & $\mathrm{mg} / \mathrm{dl}$ & $3.14 \pm 0.07$ & 2.20 & 4.20 & 22.02 & 0.692 \\
\hline \multicolumn{8}{|l|}{ Enzyme profile } \\
\hline Alkaline phosphatase & ALP & $\mathrm{U} / \mathrm{L}$ & $36.2 \pm 0.59$ & 30.00 & 48.00 & 16.25 & 5.884 \\
\hline
\end{tabular}

body development, are healthy and have a high percentage of meat.

The ionic composition and seminal plasma metabolites (Tab. 5) have a significant influence on the mobility and viability in fish semen.

In our study, in brown trout semen, $\mathrm{K}^{+}$ concentration is $12.8 \pm 0.17 \mathrm{mmol} / \mathrm{L}$, lower concentration than in Oncorhynchus mykiss (30.4 $\pm 4.5 \mathrm{mmol} / \mathrm{L}$, Glogowski et al., 2000), Salmo trutta abanticus (38 mmol/L; Bozkurt, 2008), Carassius gibelio (26.20 mmol/L, Taati et al., 2010) and higher than in Salmo trutta macrostigma (8.18 $\pm 0.03 \mathrm{mmol} / \mathrm{L}$, Bozkurt et al., 2011) and in Tinca tinca (0.6 mmol / L; Linhart et al., 2003b). In salmonids, sperm motility is controlled by the $\mathrm{K}^{+}$concentration, since it has been known since 1938 that millmolar level of extracellular $\mathrm{K}^{+}$ion concentration in the seminal tract is primarily responsible for keeping spermatozoa inactive (Schenk and Kahmann, 1938).

$\mathrm{Na}^{+}$concentration is $107 \pm 1.04 \mathrm{mmol} / \mathrm{L}$, lower concentration than in Oncorhynchus mykiss 122 $\pm 14.2 \mathrm{mmol} / \mathrm{L}$; Glogowski et al., 2000), Salmo trutta macrostigma $(121 \pm 0.37 \mathrm{mmol} / \mathrm{L}$; Bozkurt et al., 2011), but higher than in Carassius gibelio (101.59 mmol/L, Taati et al., 2010) and Tinca tinca $(18.40 \pm 1.3 \mathrm{mmol} / \mathrm{L}$; Linhart et al., 2003b). Sperm mobility also depends on other ions $\left(\mathrm{Ca}^{2+}\right.$, $\mathrm{Mg}^{2+}$ ), which presents a significant importance in initiating sperm mobility (Linhart et al., 2003a).
The mean values in $\mathrm{Ca}^{2+}$ and $\mathrm{Mg}^{2+}$ are $4.06 \pm$ $0.16 \mathrm{mg} / \mathrm{dl}$ respectively $2 \pm 0.05 \mathrm{mg} / \mathrm{dl}$, , values higher than in Oncorhynchus mykiss $\left(\mathrm{Ca}^{2+}=1.10 \pm\right.$ $0.26 \mathrm{mg} / \mathrm{dl} ; \mathrm{Mg}^{2+}=0.85 \pm 0.12 \mathrm{mg} / \mathrm{dl}$; Gallowski et al., 2000), Carassius gibelio $\left(\mathrm{Ca}^{2+}=101.59 \mathrm{mg} /\right.$ $\mathrm{dl}, \mathrm{Mg}^{2+}=0.85 \pm 0.12 \mathrm{mg} / \mathrm{dl}$, Taati et al., 2010), but lower than in Salmo trutta macrostigma $\left(\mathrm{Ca}^{2+}=\right.$ $7.23 \pm 0.03 \mathrm{mg} / \mathrm{dl} ; \mathrm{Mg}^{2+}=3.19 \pm 0.02 \mathrm{mg} / \mathrm{dl}$; Bozkurt et al., 2011). The bivalent cations $\left(\mathrm{Ca}^{2+}\right.$, $\mathrm{Mg}^{2+}$ ) are much more effective in suppressing the $\mathrm{K}^{+}$inhibitory effect on sperm motility than $\mathrm{Na}^{+}$. The effect of inhibiting $\mathrm{K}^{+}$mobility can be counteracted by increasing the concentration of $\mathrm{Ca}^{2+}$ from outside (Billiard and Cosson, 1992). The total protein from the seminal plasma has a mean value of $0.25 \pm 0.01 \mathrm{~g} / \mathrm{dl}$, a value similar to that of Salmo trutta macrostigma $(0.48 \pm 0.02$ $\mathrm{g} / \mathrm{dl}$, Bozkurt et al., 2011). Total protein has an important protective role for spermatozoa and contains a large number of key enzymes in the metabolic process. In terms of urea (BUN), higher concentrations were recorded, $12.3 \pm 0.15 \mathrm{~g} / \mathrm{dl}$, compared to Salmo trutta macrostigma (9.97 \pm $0.39 \mathrm{~g} / \mathrm{dl}$, Bozkurt et al., 2011). Contamination of sperm with urea can reduce sperm motility and fertilization capacity (Nynca et al., 2012).

Regarding the lipid profile, the mean triglyceride value is $4.13 \pm 0.07 \mathrm{mg} / \mathrm{dl}$ and cholesterol of $3.14 \pm 0.07 \mathrm{mg} / \mathrm{dl}$. Triglycerides act as sperm energy sources, both in the immobility 


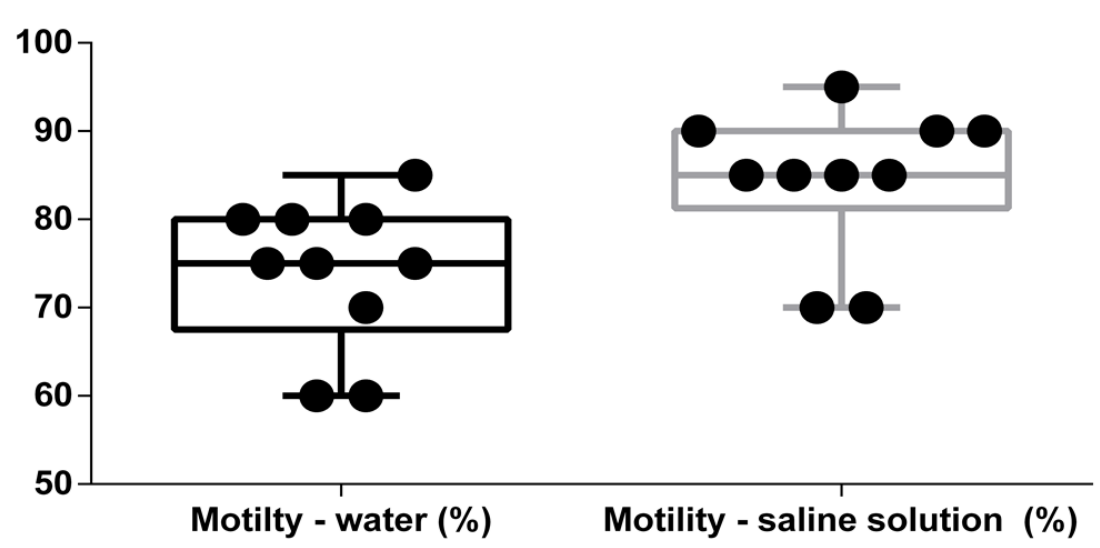

Fig. 3. Minimum, maximum and mean of mobility in water and saline solution

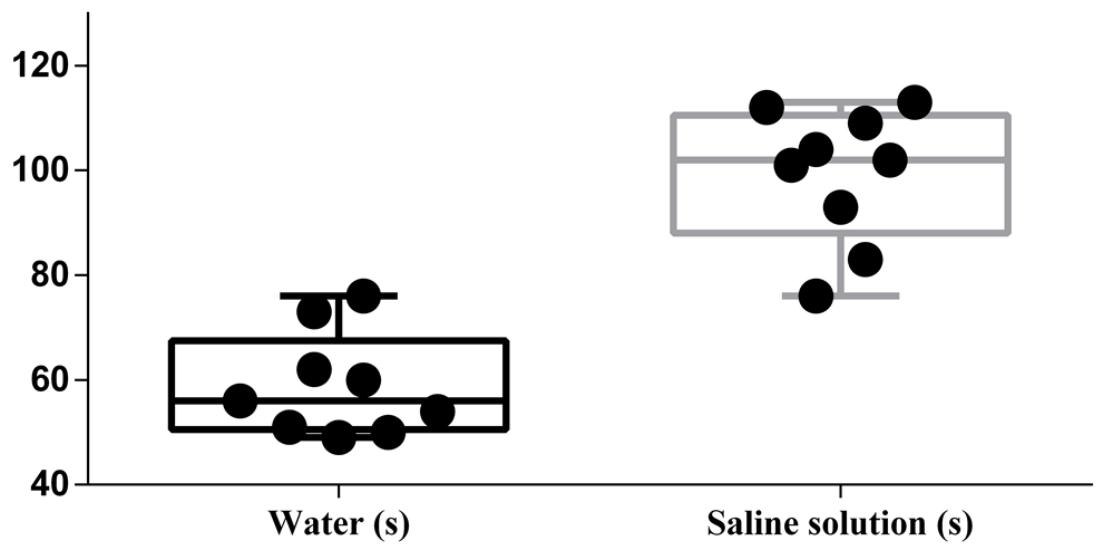

Fig. 4. Minimum, maximum and mean of mobility duration in water and in saline solution

phase and in regeneration phase after the onset of mobility. In the case of cholesterol, there is currently no information on the role it plays in seminal plasma of fish (Billiard et al., 1995). Alkaline phosphatase (ALP) activity was averaged at $36.2 \pm 0.59 \mathrm{U} / \mathrm{L}$. The ALP concentration is higher than in rainbow trout $(8.76 \mathrm{U} / \mathrm{L}$, Ciereszko and Dabrowski, 1994) but smaller that at $H$. huso $(76.13 \pm 13.56 \mathrm{U} / \mathrm{L})$ and A. stellatus $(69.05 \pm 13.04$ IU/L) (Shahsavani et al. 2007, 2008).

Figure 3 shows that in the dilution medium (water or saline solution), mobility is between $60-95 \%$, with the lowest mobility being observed in males 2 and $9(60 \%$, water) and the highest percentage in male $3(95 \%$, saline solution).

The duration of the mobility (Figure 4) is short, at the beginning the movements observed at the microscope are very energetic but gradually they become slower, oscillatory, till the spermatozoa remain immobile.
When using water as a sperm-activating medium, the duration of the mobility ranges from 49 seconds to 76 seconds, and when 7\%o saline solution was used, the values increase significantly, between 76 seconds and 113 seconds. Thus, the most important change in the duration of mobility is recorded for male 3 , where from 56 seconds it reaches 113 seconds and the slowest duration of mobility is registered for male 6 , where from 51 seconds it reaches 76 seconds.

By using saline solution as an activating factor, both mobility and mobility duration values are superior to water use. Thus, the use of saline solution increases the fecundity capacity of sperm, leading to a better rate of fecundity and implicitly to superior production. With the increase in mobility and its duration, fecundation stages are favoured, providing the necessary intervals for acrosome reaction and amphimixmia.In Figure 5 , there is shown sperm density in a millilitre of semen. In order to determine the density, we 


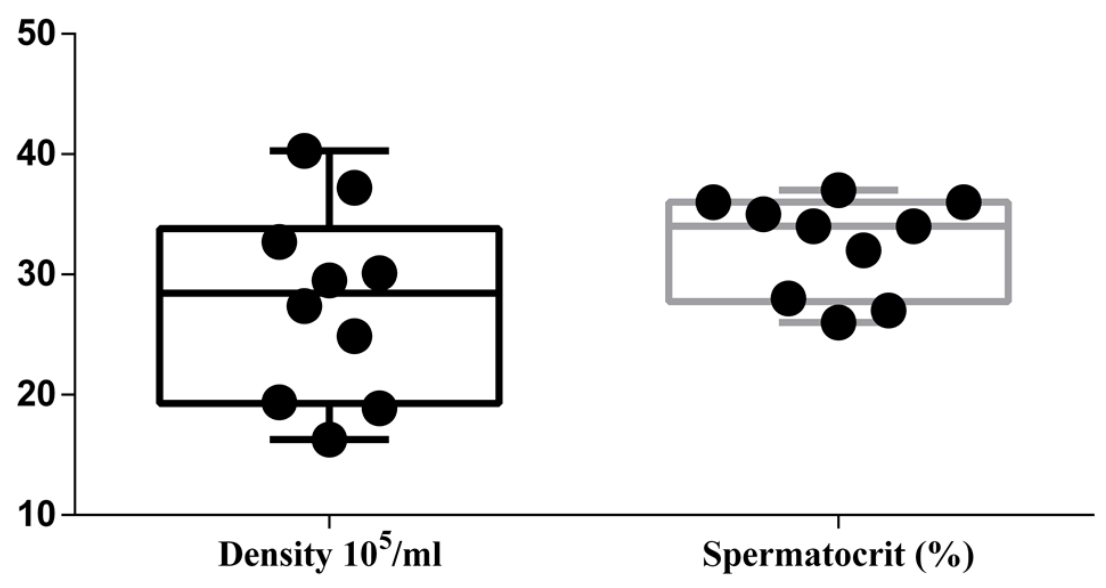

Fig. 5. Minimum, maximum and mean of spermatocrit and density of spermatozoa

used the microscopic examination, determining the spermatozoa count in one millilitre of semen, using the erythrocyte counting method. Also, spermatocrit values are represented, where the values are between 14\% (male 3 ) and 36\% (males 2 and 10 ), with a mean value of $32.5 \%$.

\section{CONCLUSIONS}

The knowledge of physical and chemical components of spermatozoa and seminal plasma is mandatory for an objective evaluation of the reproductive ability of salmonids, which leads to a better understanding of the fertilization mechanism.

As a result of researches on semen in brown trout, we noticed that saline solution $(\mathrm{NaCl})$ at a concentration of $7 \%$ compared to water when used as an activator of seminal material is much more effective in activating sperm, prolonging both the duration of their mobility and the percentage of mobile spermatozoa.

The results of this study can be used to make a rigorous selection of high quality reproductive males for the use of semen in the fertilization of roes. Thus, achieving a much higher percentage of hatching roes and much lower mortality in the development of early stages of biological material. Also, from an economic point of view, it will reduce maintenance costs for breeding males, because as a result of the rigorous selection, the number of males from the breeding group will be reduced.

Acknowledgements: We are grateful to the technical staff of Fiad trout farm, (Fiad, Bistrița-
Năsăud) for opportunities to collect brown trout semen samples.

\section{REFERENCES}

1. Alavi SMH, Cosson J (2005). Sperm motility in fishes. I. Effects of temperature and $\mathrm{pH}$ : a review. Cell Biology International 29(2):101-110.

2. Alavi SMH, Cosson J (2006). Sperm motility in fishes. II. Effects of ions and osmolality: a review. Cell Biology International 30(1):1-14

3. Billard R (1978). Changes in structure and fertilizing ability of marine and freshwater fish spermatozoa diluted in media of various salinities. Aquaculture 14:187 - 198

4. Billard R (1987a). The reproductive cycle of male and female brown trout (Salmo trutta fario): a quantitative study. Reprod. Nutr. Develop 27(1A):29 - 44

5. Billard R, Cosson MP, Christen R (1987b). Some recent data on biology on trout spematozoa. Proceedings of the 3rd International Symposium on reproductive physiology of fish:187 - 190

6. Billard R, Cosson MP (1992). Some problems related to the assessment of sperm motility in freshwater fish. Journal of Experimental Zoology, 261, 122-131.

7. Bozkurt Y (2008). Physical and biochemical properties of Salmo trutta abanticus semen. Indian Veterinary Journal, 85, 282-284

8. Bozkurt Y, Ogretmen F, Kokcu O, Ercin U (2011). Relationships between seminal plasma composition and sperm quality parameters of the Salmo trutta macrostigma (Dumeril, 1858) semen with emphasis on sperm motility. Czech J. Anim. Sci. 56(8):355-364

9. Brown DR, Shrable JB, Orr WH (1994). The use of various fertilization mediae and their effects on rainbow trout gametes. Ed. U.S. Fish and Wildlife Service, Ennis National Fish Hatchery, MT 59729

10. Ciereszko A, Dabrowski K. (1994). Relationship between biochemical constituents of fish semen and fertility: The effect of short term storage. Fish Physiology and Biochemistry 5:357-367. 
11. Ciereszko A, Dietrich GJ, Dietrich MA, Nynca J, Kuźmiński H, Dobosz S, Grudniewska J (2010). Effects of ph on sperm motility in several Salmoniformes specieis: Onchorynchus mykiss, Salmo trutta, Salmo salariu and Thymallus thymallus. Journal of Applied Ichtyology 26:742-745.

12. Cosson J, Billard R, Gibert C, Dreanno C, Linhart O, Suquet $M$ (1999). Ionic factors regulating the motility of fish sperm. Cache Rive Press:161 - 186

13. Cosson J (2004). The ionic and osmotic factors controling motility of fish spermatozoa. Aquaculture 12:69 - 85

14. Dziewulska K, Domagała J (2002). Histology of salmonid testes during maturation. Reproductive Biology, 3(1):47 $-61$

15. Glogowski J, Kwasnik M, Iros B, Dabrowski K, Goryczko K, Dobosz S. (2000) Characterization of rainbow trout milt collected with a catheter: semen parameters and cryopreservation successes. Aquat Res;31:289e96.

16. Hajirezaee S, Mojazi Amiri B, Mirvaghefi AR (2010). Relationships between the chemical properties of seminal fluid and the sperm motility characteristics of Caspian brown trout, Salmo trutta caspius (A critically endangered Salmonid fish). Research Journal of Fisheries and Hydrobiology 5(1):27-31.

17. Ingermann RL, Holocomb M, Robinson ML, Cloud JG (2002). Carbon dioxide and $\mathrm{pH}$ affect sperm motility of white sturgeons. J. Exp. Biol. 205:2885 - 2890

18. Ingermann RL, Holocomb M, Zuccarelli MD, Kanga MK Cloud J.G. (2008). Initiation of motility by steelhead (Onchorynchus mykiss) sperm: Membrane ion exchangers and $\mathrm{pH}$ sensivity. Comparative Biochemestry and Physiology 151(4):1 - 14

19. Lahnsteiner F, Berger B, Weisman T, Patzner RA (1998). Determination of semen quality of the rainbow trout Onchorynchus mykiss, by sperm motility, seminal plasma and spermatozoal metabolism. Aquaculture 163(12):163-181.

20. Lahnsteiner F. (2007). Characterization of seminal plasma proteins stabilizing the sperm viability in rainbow trout, Onchorynchus mykiss. Animal Reproduction Science 97(12):151-164.

21. Lahnsteiner F, Mansour N, Plaetzer K (2010). Antioxidant systems of brown trout ( Salmo trutta fario) semen. Animal Reproduction Science 119(3-4): 314-321.

22. Linhart O, Cosson J, Mims SD, Rodina M, Gela D, Shelton WL. (2003a). Effects of ions on the motility of fresh and demembranated sperm of common carp (Cyprinus carpio) and paddlefish (Polyodon spathula). Fish Physiol. Biochem.;28:203:5.

23. Linhart O, Rodina M, Bastl J, Cosson J. (2003b). Urinary bladder, ionic composition of seminal fluid and urine with characterization of sperm motility in tench (Tinca tinca L.). J Applied Ichthyology 19:177:81.

24. Nynca J, Ciereszko A (2009) Measurment of concentrations and viability of brook trout (Salvelinus fontinalis) spermatozoa using computer-aided fluorescent microscopy. Aquaculture 292:256-258.

25. Nynca J, Dietrich GJ, Kuźmiński H, Dobosz S, Ciereszko A (2012). Motility activation of rainbow trout spermatozoa at $\mathrm{pH}$ 6,5 directly related to contamination of milt with urine. Aquaculture 330-333:185-188.

26. Rurangwa E, Kime DE, Ollevier F, Nash JP (2004). The measurement of sperm motility and factors affecting sperm quality in fish. Aquaculture 234(1-4):1-28

27. Schlenk W, Kahmann H (1938). The chemical composition of seminal fluids and their physiological importance study with trout sperm. Biochem Zool 295:283-301.

28. Shahsavani D, Mohri M, Taghvaiemoghadam E. (2007). Determination of concentration of some blood serum enzymes in Huso huso. Journal of Veterinary Research University of Tehran 62:127-129.

29. Shahsavani D, Mohri M, Gholipour Kanani H. (2008). Determination of normal values of some blood serum enzyme in Acipenser stellatus. Fish Physiology and Biochemistry 36:39-43

30. Taati MM, Mehrad B, Shabani A, Golpur A (2010). Correlation between chemical composition of seminal plasma and sperm motility charachteristics of Prussian carp (Carassius gibelio). AACL Bioflux 3(3):233-238

31. Woolsey J, Holocomb M, Cloud JG, Ingermann R.L. (2006). Sperm motility in the steel-head Onchorynchus mykiss (Walbaum): influence of the composition of the incubation and activation mediae. Aquaculture Research 37:215-223.

32. Zuccarelli MD, Ingermann RL (2007). Exhaustive exercise, animal stres and environementall hypercapnia on motility of sperm of steelhead trout (Onchorynchus mykiss). Comparative Biochemestry and Physiology Part A: Molecular \& Integrative Physiology 147(1):247 - 253

33. www.aller-aqua.com 